Egyptian Journal of Aquatic Biology \& Fisheries

Zoology Department, Faculty of Science,

Ain Shams University, Cairo, Egypt.

ISSN $1110-6131$

Vol. 24(3): 85 - 95 (2020)

www.ejabf.journals.ekb.eg

\title{
Length-weight, condition factor and reproductive aspects of the cobia, Rachycentron canadum (Linnaeus, 1766) in the Arabian Gulf off the United Arab Emirates
}

\author{
Elsayed F. E. Farrag " and Ahmed M. Alzaabi \\ Marine Environment Research Department, Ministry of Climate Change and Environment, Dubai \\ P.O. Box 1509, Dubai, United Arab Emirates \\ *Corresponding Author: eefarrag@gmail.com
}

\section{ARTICLE INFO}

Article History:

Received: March 25, 2020

Accepted: May 8, 2020

Online: May 14, 2020

Keywords:

Arabian Gulf,

Cobia,

Condition factor,

Length-weight relationship,

Rachycentron canadum.

\section{ABSTRACT}

The present study provides the basic information in the fisheries biology and stock assessment for the cobia, Rachynentron canadum in the Southern part of the Arabian Gulf off the United Arab Emirates. A total of 371 individuals were sampled. The length-weight relationships of $R$. canadum were estimated as $\mathrm{W}=0.0022 * \mathrm{~L}^{3.2536}$, $\mathrm{R}^{2}=0.99$ for all individuals, $\mathrm{W}=0.0028 * \mathrm{~L}^{3.1875}, \quad \mathrm{R}^{2}=0.98$ for males and $\mathrm{W}=0.0022 * \mathrm{~L}^{3.258}, \mathrm{R}^{2}=0.99$ for females. According to $b$ values, the growth type of this species was positive allometric growth $(\mathrm{b}>3)$, (t-test: $\mathrm{p}<0.05)$. Condition factors ranged from 0.60 to 0.77 for males and from 0.61 to 0.85 for females, while the relative condition factor for males ranged between 0.92 and 1.07 and between 0.96 and 1.14 for females. The monthly calculated mean values of the gonado-somatic index (GSI) of females increased from April, reaching the highest value in May then declined in July. The male/female ratio of this species was $1 / 1.82$. The length at first sexual maturity for $R$. canadum was estimated at $63.31 \mathrm{~cm}$ and $75.08 \mathrm{~cm}$ TL for males and females respectively.

\section{INTRODUCTION}

The cobia Rachycentron canadum is large, coastal, pelagic fish of the monotypic family Rachycentridae that distributed in tropical and subtropical waters, but absent in the eastern Pacific (Herre 1953, Robins \& Ray 1986 and Shaffer \& Nakamura 1989). Length and weight data are useful and widely used in fisheries science for estimation of the weight for a given length, estimation of biomass when length frequency distribution is known and the estimation of condition indices (Froese et al., 2011). On the other hand, the knowledge of the length-weight relationship makes it easier to determine the mass where only the length is known (Kara \& Bayhan, 2008). Condition factor at different body lengths can give valuable information on maturation and spawning of the fish, whereas seasonal variation in the condition factor values may give definite clues regarding the breeding seasons (Le Cren, 1951). Condition factor decrease with increase in length (Bakare, 1970 and Fagade, 1979); and also influences the reproductive cycle in fish (Welcome, 1979).

The reproductive biology of a species will provide vital information on its life history traits, which will be of use in management and conservation of the resources, as well as in 
evolving aquaculture and husbandry practices. Many biological characteristics of cobia have been investigated by several authors. The length weight relationship and condition factor from Indian waters were estimated by Sajeevan \& Kurup (2017) and Maharshi et al. (2017). The feeding intensity, systematics, distribution and abundance of cobia inhabiting Indian waters were provided by Sajeevan \& Kurup (2013; 2014 a\&b). Preliminary information on reproductive biology of cobia from Indian waters were provided by many authors (Rajan et al., 1968; Somvanshi et al., 2000; Pillai et al., 2009; Ganga et al., 2012 and Sajeeven \& Kurup, 2017). Richards (1967), Smith (1995) and Lotz et al. (1996) have reported the size at maturity of cobia from other parts of the world.

Despite the popularity of cobia, little is known about the status of the fishery or the life history of this species along the Arabian Gulf. The purpose of the present study was to better define the life-history characteristics of cobia so that managers will have the preliminary information required to accurately manage this species.

\section{MATERIALS AND METHODS}

\section{Fish samples:}

Samples of Rachycentron canadum were collected from the commercial catches landed at the landing sites off the United Arab Emirates during the period from January to December 2017. Total length $(\mathrm{cm})$ and total weight $(\mathrm{g})$ were recorded for each sampled specimen. To avoid any bias resulted from weights of gonads and stomachs, the gutted weight ( $W g$ ) was used. Sex and maturity stages were macroscopically determined and recorded. Weight of gonads $(G W)$ was recorded to the nearest $0.01 \mathrm{~g}$. Stages of maturity were classified as follows: I immature; II developing; III mature; IV ripe; V running ripe; and VI spent according to Nikolsky (1963).

\section{Length weight relationship}

The relationship between the length $(L)$ and weight $(W)$ of fish was expressed by equation of Pauly (1983): $W=a L^{b}$ where $W$ is the weight of fish in $\mathrm{g}, L$ is the total length of fish in $\mathrm{cm}, a$ is a constant and $b$ is the slope of the relation. The relationship was established for both males and females by linear regression of the logarithms of the length and weight data following Pauly (1983). Bailey's t-test (Snedecor \& Cochran, 1967) was employed to find out whether $b$ value significantly deviated from the expected cube value of $3\left[t=(b-3) / S_{b}\right]$, where $b$ is the regression coefficient and $S_{b}$ is the standard error of the slope.

\section{Condition factor}

The Fulton's condition Factor $K_{c}$ was calculated employing the formula of Fulton (1904) as $K_{c}=W / L^{3 * 100}$ where: $K_{c}$ is the condition factor, $W$ is the weight of fish, $\mathrm{L}$ is the length of fish. Relative condition factor $K_{n}$ was established to assess the condition of the species under study. $K_{n}$ is defined as $W / \hat{W}$ where $\mathrm{W}$ is the observed weight and $\hat{W}$ is the calculated weight derived from length-weight relationship (Le-Cren, 1951). Good growth condition of the fish is deduced when $\mathrm{K}_{\mathrm{n}} \geq 1$, while the organism is in poor growth condition compared to an average individual with the same length when $K_{n}<1$.

\section{Reproductive biology}

Gonado-somatic index GSI was calculated monthly for both males and females of $R$. canadum by the following equation: $G S I=W G / W g * 100$ where: $G W$ is the fish gonad weight and $W g$ is the fish gutted weight as mentioned by Claereboudt $\boldsymbol{e t}$ al. (2005). The sex ratio (male: female) was calculated and the significant differences from the theoretical ratio (1.0: 1.0) were tested by means of chi-squared test $\chi^{2}$ (Sokal \& Rohlf, 1981). The length at which $50 \%$ of all 
individuals were sexually mature $L_{50}$, was estimated from the proportion of mature individuals in each $5.0 \mathrm{~cm}$ length class and the fitted logistic curve (King, 1995) as follows: $P=1 / 1+\exp \left[r^{*}(L\right.$ $\left.\left.L_{50}\right)\right]$ where $P$ is the proportion of mature individuals within a length class, $r$ is the slope of the curve, and $L_{50}$ is the length at $50 \%$ sexual maturity.

\section{RESULTS}

\section{Length-weight relationship}

A total of 371 specimens of $R$. canadum were collected (236 females, 130 males and 5 unsexed), the total length of males, females and pooled data varied from 44.0 to $110 \mathrm{~cm}$ with average of $66.95 \mathrm{~cm}$; from 40.0 to $163 \mathrm{~cm}$ with average of $82.29 \mathrm{~cm}$ and from 36.0 to $163.0 \mathrm{~cm}$ with average of $76.0 \mathrm{~cm}$, respectively. Sample sizes (n), minimum and maximum values of lengths and weights, as well as parameters $a$ and $b$ of the length-weight relationship and the coefficient of determination $r^{2}$ are given in Table (1).

Table (1): Descriptive statistics and estimated parameters of length-weight relationships for males, females and pooled data of R.canadum.

\begin{tabular}{|c|c|c|c|c|c|c|}
\hline Sex & $\mathbf{N}$ & TL range (cm) & Wt. range (g) & $\mathbf{a}$ & $\mathbf{b}$ & $\mathbf{r}^{\mathbf{2}}$ \\
\hline Males & 130 & $44-110$ & $531-10864$ & 0.0028 & 3.188 & 0.98 \\
\hline Females & 236 & $40-163$ & $375-36400$ & 0.0022 & 3.258 & 0.99 \\
\hline Pooled & 371 & $36-163$ & $264-36400$ & 0.0022 & 3.254 & 0.99 \\
\hline
\end{tabular}

N: sample size, TL: total length, Wt.: weight, a and b: parameters of length-weight relationship

The length-weight relationship of $R$. canadum was estimated as: $\mathrm{W}=0.0028 * \mathrm{~L}^{3.1875}$, $\mathrm{r}^{2}=0.98$ for males; $\mathrm{W}=0.0022 * \mathrm{~L}^{3.258}, \mathrm{r}^{2}=0.99$ for females and $\mathrm{W}=0.0022 * \mathrm{~L}^{3.2536}, \mathrm{r}^{2}=0.99$ for pooled data of both sexes (Figures 1-3). The analysis of covariance indicated no significant difference in the regression coefficients. As may be seen from the equations, the coefficient of correlation, $\mathrm{r}^{2}$ for both sexes and pooled data of total length and body weight are identical and equal to 0.99 which is highly significant at $1 \%$ level. According to the t-test, there is a significant difference between $b$ value and the cube value in both sexes and pooled data. This indicates that both males and females follow positive allometric growth. The corresponding logarithmic regression equations can be represented as follows: $\log \mathrm{W}=-2.5414+3.1875^{*} \mathrm{Log} \mathrm{L}$ for males; $\log \mathrm{W}=-2.6566+3.258 * \log \mathrm{L}$ for females and $\log \mathrm{W}=-2.6538+3.2536 * \log \mathrm{L}$ for pooled data.
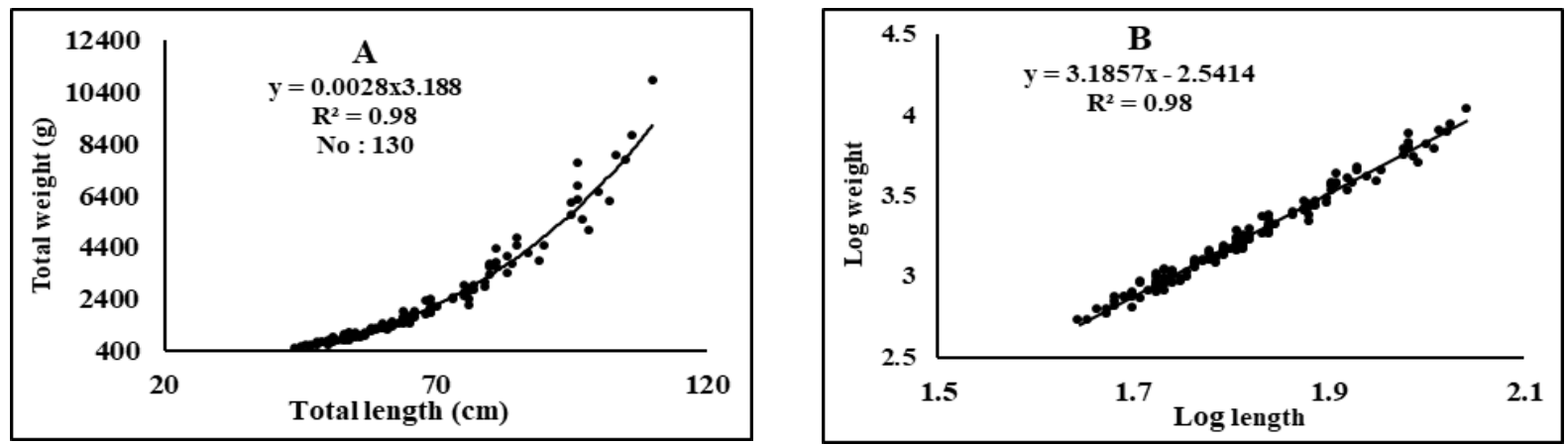

Figure 1. Length-weight relationship of males $R$. canadum (A) power equation and (B) logarithmic relationship 

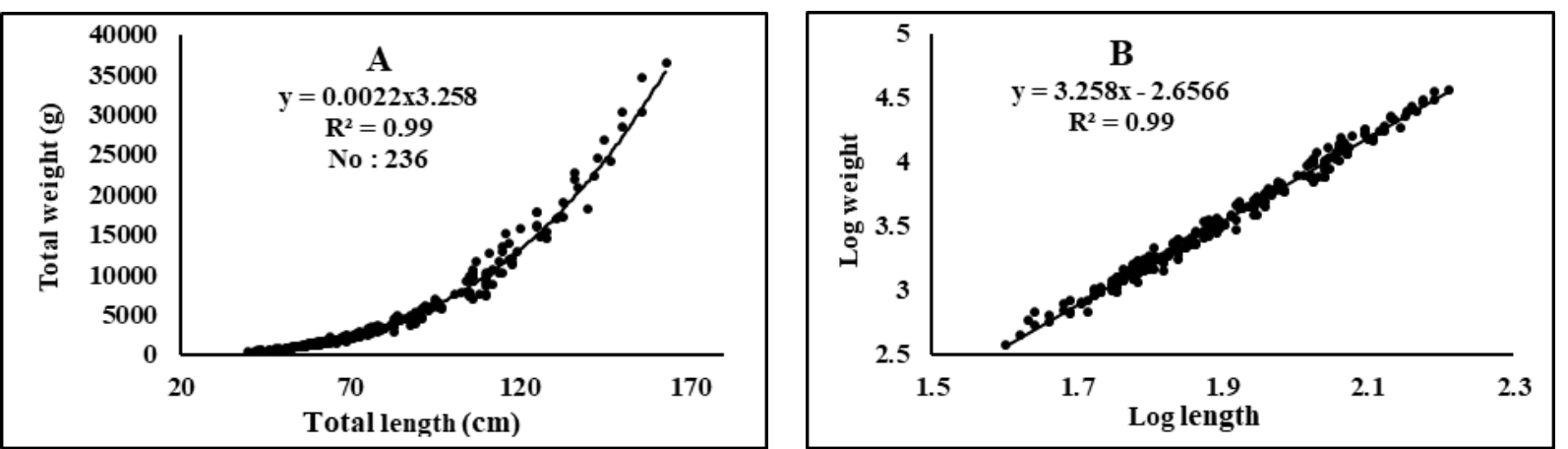

Figure 2. Length-weight relationship of females $R$. canadum (A) power equation and (B) logarithmic relationship
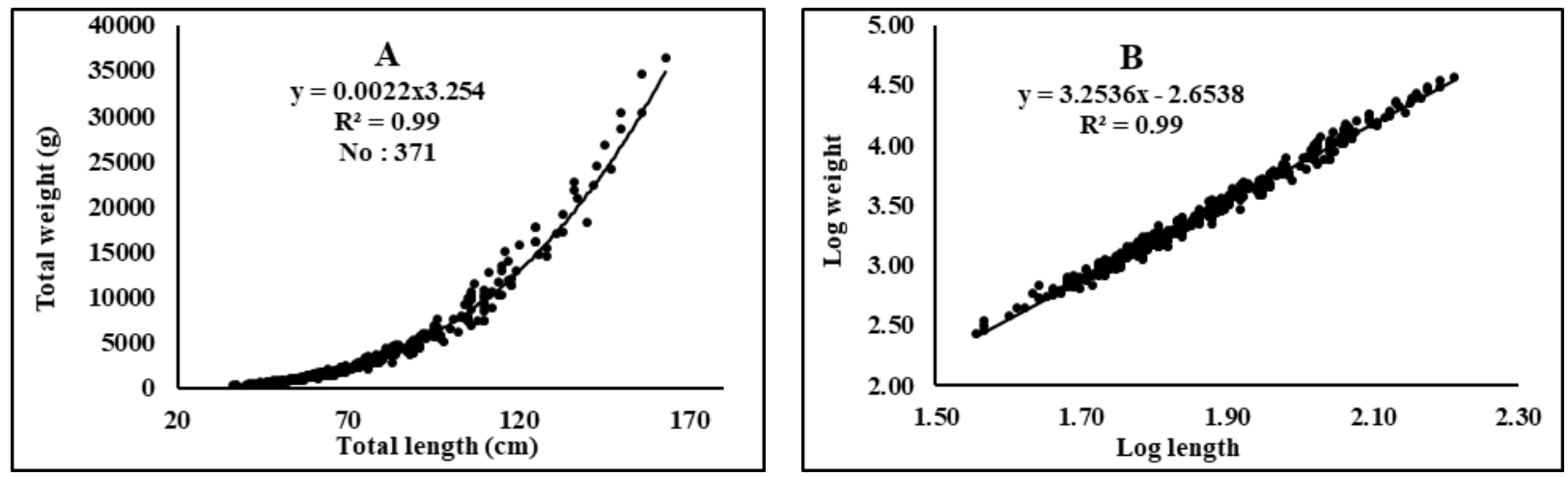

Figure 3. Length-weight relationship of combined sexes R.canadum (A) power equation and (B) logarithmic relationship

\section{Condition factor and relative condition factor}

Figure (4) shows the seasonal fluctuation of the condition factor $K_{c}$ for both sexes, the results revealed that, the maximum values of condition factor were recorded during Summer (0.70 and 0.71) and the minimum values occurred in Autumn (0.61 and 0.64) for males and females respectively. In general, the mean value of condition factor of females higher than that of males. On the other hand, the relative condition factor $K_{n}$ was estimated for both sexes and declared that, the maximum and minimum values of relative condition factor were estimated during Summer and Autumn respectively. Generally, the mean value of $K_{n}$ in males (1.06) was higher than that of females (1.01).
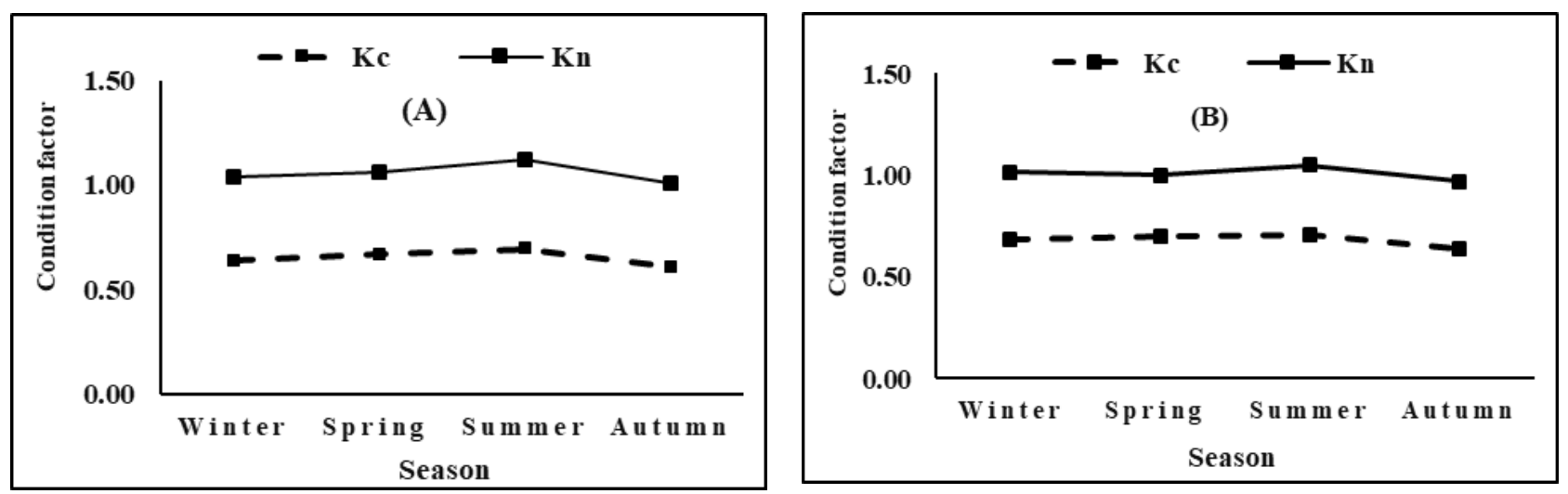

Figure 4. Seasonal variations of $\mathrm{Kc}$ and $\mathrm{Kn}$ of males (A) and females (B) R. canadum 
The average condition factor Kc at different length groups for both sexes was calculated and tabulated in Table (2). In females, the average Kc values were found to vary from $0.61 \pm 0.053$ to $0.85 \pm 0.057$ while in males ranged from $0.60 \pm 0.044$ to $0.77 \pm 0.059$. It was observed that the value of Kc tends to be lower between 46 and $65 \mathrm{~cm}$ length group in females and from 56 to $65 \mathrm{~cm}$ in males indicating that these length groups were in the worst condition. The higher Kc values in females was gradually increased from length group 126-135 cm and reached to the maximum value 0.85 in the largest length group $156-165 \mathrm{~cm}$; in males it was recorded in length group 106-115 $\mathrm{cm}$. However, the value of relative condition factor Kn was observed to vary from $0.96 \pm 0.048$ to $1.14 \pm 0.147$ for females and between $0.92 \pm 0.080$ to $1.07 \pm 0.075$ in males. The lowest value of $\mathrm{Kn}$ was seen in 126-135 cm length group in females and in length group 86-95 cm in males. Whereas, the highest value of $\mathrm{Kn}$ was found in the length group of 36-45 cm in females and in length group 106-115 cm for males. Generally, the average $\mathrm{Kc}$ and $\mathrm{Kn}$ in females was higher than that in males.

Table 2. Variation in condition factor $\mathrm{Kc}$ and relative condition factor $\mathrm{Kn}$ of $\boldsymbol{R}$. canadum with different length groups

\begin{tabular}{|c|c|c|c|c|c|c|c|c|c|c|}
\hline \multirow{2}{*}{ Length group } & \multicolumn{5}{|c|}{ Females } & \multicolumn{5}{|c|}{ Males } \\
\hline & No & Kc & SD & Kn & SD & No & Kc & SD & Kn & SD \\
\hline $36-45$ & 5 & 0.66 & 0.089 & 1.14 & 0.147 & 2 & 0.61 & 0.022 & 1.06 & 0.042 \\
\hline $46-55$ & 21 & 0.61 & 0.053 & 1.01 & 0.089 & 36 & 0.61 & 0.050 & 1.02 & 0.085 \\
\hline $56-65$ & 62 & 0.64 & 0.059 & 1.01 & 0.091 & 37 & 0.60 & 0.044 & 0.96 & 0.069 \\
\hline $66-75$ & 32 & 0.64 & 0.072 & 0.97 & 0.106 & 19 & 0.63 & 0.050 & 0.98 & 0.078 \\
\hline $76-85$ & 26 & 0.68 & 0.075 & 1.00 & 0.110 & 20 & 0.66 & 0.080 & 0.99 & 0.115 \\
\hline $86-95$ & 22 & 0.69 & 0.070 & 0.98 & 0.096 & 5 & 0.63 & 0.060 & 0.92 & 0.080 \\
\hline $96-105$ & 14 & 0.71 & 0.075 & 0.98 & 0.100 & 9 & 0.68 & 0.101 & 0.96 & 0.146 \\
\hline 106-115 & 23 & 0.75 & 0.120 & 1.01 & 0.162 & 2 & 0.77 & 0.059 & 1.07 & 0.075 \\
\hline 116-125 & 12 & 0.82 & 0.096 & 1.09 & 0.125 & & & & & \\
\hline 126-135 & 6 & 0.75 & 0.039 & 0.96 & 0.048 & & & & & \\
\hline 136-145 & 7 & 0.82 & 0.081 & 1.05 & 0.104 & & & & & \\
\hline 146-155 & 3 & 0.84 & 0.070 & 1.05 & 0.084 & & & & & \\
\hline $156-165$ & 3 & 0.85 & 0.057 & 1.05 & 0.072 & & & & & \\
\hline No. & 236 & & & & & 130 & & & & \\
\hline Av. & & 0.73 & 0.074 & 1.02 & 0.103 & & 0.65 & 0.058 & 0.99 & 0.086 \\
\hline
\end{tabular}

\section{Reproductive biology \\ Sex ratio}

The total number of female samples was greater than that of males. The estimated sex ratio for all samples was 0.55 which significantly differed $\left(\mathrm{X}^{2}=57.92 ; p<0.01\right)$ from the expected 0.05. The proportion of females was higher than males in all months except June and September (predomination of males). Table (3) gives our results on the sex of the 366 specimens of $R$. canadum collected during the study period, grouped by month. The sex ratio of the collected samples was $1: 1.82$ males to females, respectively. 
Table 3. Sex ratio of $R$. canadum collected during 2017.

\begin{tabular}{|c|cc|cc|c|}
\hline \multirow{2}{*}{ Month } & \multicolumn{2}{|c|}{ Females } & \multicolumn{2}{c|}{ Males } & \multirow{2}{*}{$\begin{array}{c}\text { Sex ratio } \\
\text { M : F }\end{array}$} \\
\cline { 2 - 5 } & No & $\mathbf{\%}$ & No & \% & $1: 1.10$ \\
\hline Jan. & 11 & 52 & 10 & 48 & $1: 1.53$ \\
\hline Feb. & 23 & 61 & 15 & 39 & $1: 1.33$ \\
\hline Mar. & 16 & 57 & 12 & 43 & $1: 4.75$ \\
\hline Apr. & 19 & 83 & 4 & 17 & $1: 7.80$ \\
\hline May. & 39 & 89 & 5 & 11 & $1: 0.79$ \\
\hline Jun. & 11 & 44 & 14 & 56 & $1: 1.43$ \\
\hline Jul. & 10 & 59 & 7 & 41 & $1: 21.0$ \\
\hline Aug. & 21 & 95 & 1 & 5 & $1: 0.54$ \\
\hline Sep. & 20 & 35 & 37 & 65 & $1: 2.40$ \\
\hline Oct. & 24 & 71 & 10 & 29 & $1: 1.73$ \\
\hline Nov. & 19 & 63 & 11 & 37 & $1: 5.75$ \\
\hline Dec. & 23 & 85 & 4 & 15 & $\mathbf{1}: \mathbf{1 . 8 2}$ \\
\hline total & $\mathbf{2 3 6}$ & $\mathbf{6 4}$ & $\mathbf{1 3 0}$ & $\mathbf{3 6}$ & \\
\hline
\end{tabular}

\section{Gonado-Somatic Index and sexual maturity}

The calculated means of monthly gonado-somatic index for males and females of $R$. canadum are presented in Figure (5). The monthly calculated mean values of (GSI) of males and females were indicate to increase from April, reached its highest value in May and declined in July. It could be concluded that there was one peak of spawning period for $R$. canadum in May. The gonado-somatic index ranged in the females from 0.51 to 2.43 with a mean of $1.0 \pm 0.57$. While in males, the gonado-somatic index ranged from 0.25 to 2.33 with a mean of $0.87 \pm 0.71$. The smallest sexually mature male was $54.0 \mathrm{~cm}$ TL whereas the same for female was $60.0 \mathrm{~cm}$ TL. Based on graphical methods, $50 \%$ sexual maturity $\left(\mathrm{L}_{50 \%}\right)$ of $R$. canadum was recorded at $63.31 \mathrm{~cm}$ TL for males and at 75.08 $\mathrm{cm}$ TL for females (Figure 6).

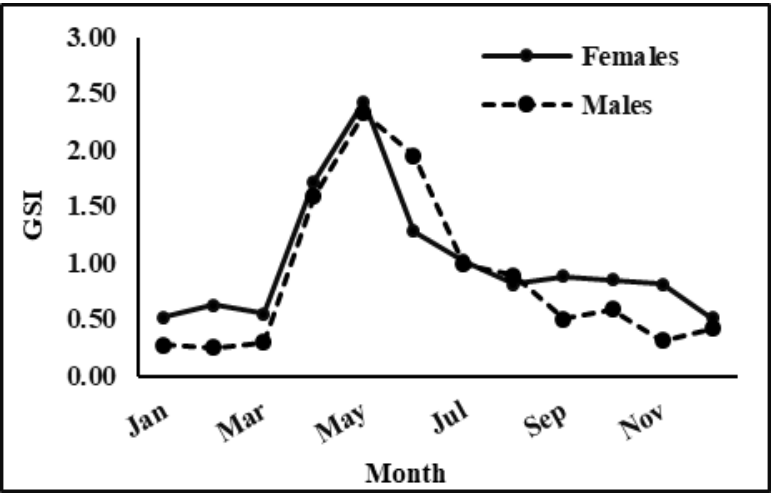

Figure 5. Seasonal variation in gonadosomatic index for $R$. canadum

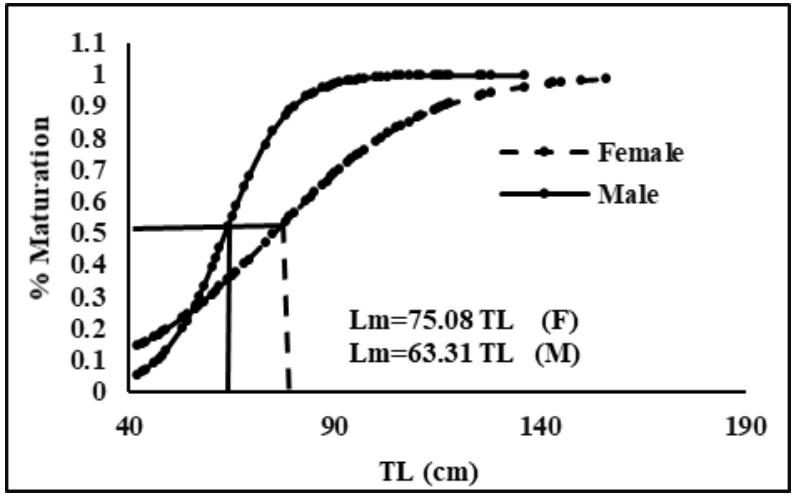

Figure 6. Length at first sexual maturity $L_{m}$ for $R$. canadum

\section{DISCUSSION}

The length weight relationship parameters ( $a$ and $b$ ) of the fish are affected by a series of factors such as season, habitat, gonad maturity, sex, diet, stomach fullness, health and annual differences in environmental conditions (Bagenal \& Tesch, 1978 and Froese, 2006). Weight of fish increases logarithmically with an increase in length, with 
the slope value $b$ lying between 2.5 and 3.5, similar studies done by Carlander $\boldsymbol{e t}$ al. (1969). In the present study, the $b$ values obtained for males and females were 3.19 and 3.26 respectively, suggesting that females were heavier and grow faster than males and the exponent $b$ close to 3.0. Length weight relationship of cobia reported by various authors from different parts of the world are furnished in Table (4).

Table 4. Length-weight relationship of $R$. canadum reported by different authors from different localities

\begin{tabular}{|c|c|c|c|c|c|}
\hline Area of study & Author/s & Sex & $\begin{array}{l}\text { Length } \\
\text { (TL/FL) }\end{array}$ & $\mathbf{a}$ & b \\
\hline Northeastern Gulf of Mexico & Franks et al. 1999 & Pooled & FL & 0.0015 & 3.428 \\
\hline North west coast of India & Somvanshi et al. 2000 & $\begin{array}{c}\text { Male } \\
\text { Female }\end{array}$ & $\mathrm{TL}$ & $\begin{array}{l}0.0096 \\
0.0036\end{array}$ & $\begin{array}{c}2.874 \\
3.1603\end{array}$ \\
\hline Gulf of Mexico & Williams, 2001 & Pooled & FL & $10.8 \times 10^{-8}$ & 2.970 \\
\hline South west Coast of India & Abdurahiman et al. 2004 & $\begin{array}{c}\text { Male } \\
\text { Female }\end{array}$ & $\mathrm{TL}$ & $\begin{array}{l}0.010 \\
0.004\end{array}$ & $\begin{array}{l}2.876 \\
3.092\end{array}$ \\
\hline Northwest Coast of India & Sajeevan and Madhusoodana, 2015 & $\begin{array}{c}\text { Male } \\
\text { Female } \\
\text { Pooled }\end{array}$ & TL & $\begin{array}{c}0.0044 \\
0.00396 \\
0.00421\end{array}$ & $\begin{array}{c}3.078 \\
3.1075 \\
3.0895\end{array}$ \\
\hline South East Coast of India & Maharshi et al. 2017 & $\begin{array}{l}\text { Male } \\
\text { Female }\end{array}$ & $\mathrm{TL}$ & $\begin{array}{l}0.00469 \\
0.00219\end{array}$ & $\begin{array}{c}3.1165 \\
3.364\end{array}$ \\
\hline $\begin{array}{l}\text { South Coast of Arabian Gulf } \\
\text { off Emirates }\end{array}$ & Present study & $\begin{array}{c}\text { Male } \\
\text { Female } \\
\text { Pooled }\end{array}$ & TL & $\begin{array}{l}0.0028 \\
0.0022 \\
0.0022\end{array}$ & $\begin{array}{l}3.188 \\
3.256 \\
3.254\end{array}$ \\
\hline
\end{tabular}

Condition factor values were assessed for males and females of $R$. canadum. Data were analyzed for various length group and for different months to understand the wellbeing of the species and also to infer information on reproductive behavior, feeding habits etc. (Froese, 2006). According to Bennet (1970), Fulton's condition factor $\geq 0.56$, relative condition factor $\geq 1$ and are considered as well-being bench mark values of a fish, hence fishes with condition factor values above the well-being bench mark were considered to be in good condition. Result of the present study indicated that $R$. canadum occurring in southern part of Arabian Gulf in good condition throughout the study period. Sajeevan \& Madhusoodana (2015) declared the male of $R$. canadum was in good condition throughout the year except during October, in which they were in average condition, while in female the condition factor values during August, October and November were below 0.56 .

The overall sex-ratio (M: F) for $R$. canadum was 1.0:1.82 which is deviated from the expected 1:1 in favor of females. This agrees with the results obtained for the same species in Chesapeake Bay and adjacent mid-Atlantic waters (Richards, 1967), in northern part of the Arabian Gulf off Iranian water (Daghooghi et al., 2008), in the northeastern Gulf of Mexico (Franks et al., 1999). On the contrary, sex ratios of the same species where male population dominate over females were reported in Louisiana waters (Thompson et al., 1991). In South Carolina, the ratio of males to females was 1.0:1.1 (Kalinowsky et al., 2016). In the present study the spawning season was recorded from April to June with peak in May. Joseph et al. (1964) mentioned the presence of gravid females and appearance of cobia eggs in plankton collections indicated that spawning occurs between mid-June and mid-August in the Atlantic Ocean adjacent to the mouth of the Chesapeake Bay. Richards (1967) indicated that cobia spawn from late June through mid-August off Virginia. In the Caribbean Sea, Erdman (1968) indicated that August was the peak month of spawning for cobia in Puerto Rican waters. A female with maturing eggs was collected from Madagascar waters in October 1964 (Richards 1967). In the Indian waters, Day (1967) took a ripe female in March; Darracott (1977) 
indicated that cobia eggs have not yet been recorded from the Indian Ocean, although ripe fish are found year-round. She also indicated that cobia may migrate from the southern Indian Ocean to spawn off coastal areas of the Arabian Sea. In Pakistan waters, ripe cobia is found in March and April along the Baluchistan coast (Bianchi, 1985). In Iranian waters, Daghooghi et al. (2008) declared the spawning season during spring and summer with main peak in June

The estimated size of $50 \%$ maturity $\left(\mathrm{L}_{50 \%}\right)$ for females and males of $R$. canadum in this study was 75.08 and $63.31 \mathrm{~cm}$, respectively. The smallest sexually-mature length was 60.0 and $54.0 \mathrm{~cm}$ for females and males, respectively. The sizes at first maturity reported by different authors from various localities are shown in Table (5). The results of the present study are in concurrence with these findings. However, all the studies are concurrent in reporting that size at maturity of male and female differs from each other. The present study indicates that male cobia matures at smaller length than female, as reported by other workers (Williams, 2001; Kaiser \& Holt, 2005; Tonya et al. 2010 and Sajeevan \&Madhusoodana, 2017). In contrast, Rajan et al. (1968) found that male mature at length larger than females.

Table 5. Length at first maturity of R.canadum reported by various authors from different localities

\begin{tabular}{|c|c|c|c|}
\hline \multirow{2}{*}{ Area of study } & \multirow{2}{*}{ Author/s } & \multicolumn{2}{|c|}{ Length at first maturity $(\mathrm{cm})(\mathrm{TL} / \mathrm{FL})^{*}$} \\
\hline & & Female & Male \\
\hline Chilka Lake, India & Rajan et al. 1968 & 42.6 (TL) & ---- \\
\hline Gulf of Mexico & Williams, 2001 & 84.5 ( FL) & $64.0 \quad($ FL) \\
\hline Texas, USA & Kaiser and Holt, 2005 & 83.4 ( FL) & $64.0(\mathrm{FL})$ \\
\hline North-eastern Australia & Tonya et al. 2010 & 78.4 ( FL) & $77.0 \quad(\mathrm{FL})$ \\
\hline North-west Coast of India & Sajeevan and Kurup, 2017 & $70.0 \quad$ (TL) & 63.0 (TL) \\
\hline Present study & & 75.8 (TL) & $63.31 \quad(\mathrm{TL})$ \\
\hline
\end{tabular}

*TL: total length, FL forked length

\section{CONCLUSION}

In conclusion, this paper provides the basic information of the large, economically important fish species in the southern part of the Arabian Gulf, Rachycentron canadum. The analyzed data shows positive allometric growth rate and the weight of fish increase logarithmically with an increase in length, as a result of the small number of samples, it is possible that these results will change if the number of samples increases. This the first report on length weight, condition factor and some reproductive aspects of the R.canadum off the Emirates coastline and could strongly helpful to the researchers and policy makers for the preparation of very effective sustainable management plans of fishery resources.

\section{REFERENCES}

Abdurahiman, K. P.; Harishnayak, T.; Zacharia, P. U. and Mohamed, K. S. (2004). Length-weight relationship of commercially important marine fishes and shellfishes of the southern coast of Karnataka, India. Naga World Fish Center Q. 27 (1\& 2): 9-14 
Bagenal, T.B. and F.W. Tesch. (1978). Age and growth. In: T. Begenal (Ed.), Methods for assessment of fish production in fresh waters, 3rd Edn. IBP Handbook No. 3, Blackwell Science Publications, Oxford: pp.101-136.

Bakare, O. (1970). Bottom Deposits as Food of Inland Fresh Water Fish. In: Kainji, A Nigerian man-made lake. S.A. Visser, (Ed.)., Kanji Lake Studies Vol. 1. Ecology Published for the Nigerian Institute.

Bennet, G. W. (1970). Management of lakes and ponds.. Van Nostrand Reinhold, New York, 385pp.

Bianchi, G. (1985). Field Guide to the Commercial Marine and Brackish-Water Species of Pakistan. FAO, Rome, 200pp.

Carlander, K. (1969). Hand book of freshwater fishery biology, 1. Jowa State University press, Ames. $752 \mathrm{pp}$.

Claereboudt, M. R.; McIlwain, J. L.; Al-Oufi, H. S. and Abu-Ali, A. A. (2005). Patterns of reproduction and spawning of the kingfish (Scomberomorus commerson, Lac'ep`ede) in the coastal waters of the Sultanate of Oman" Department of Marine Science and Fisheries, College of Agricultural and Marine Sciences. Fisheries Research No (73): 273-282.

Daghooghi, B.; Darvishi, M.; Behzadi, S.; Safaei, M.; Forooghifard, H.; Kamali, I.; Valinassab, T.; and Matinfar, A. (2008). A survey of some biological aspects of cobia (Rachycentron canadum). Tehran, Iran, Iranian Fisheries Science Research Institute, 85pp.

Darracott, A. (1977). Availability, morphometrics, feeding and breeding activity in a multi-species, demersal fish stock of the western Indian Ocean. J. Fish. Biol. I0(1): 1-16.

Day, F. (1967). The fishes of India, vol. 1, p. 256-257. Today \& Tomorrow's Book Agency, New Delhi, India.

Erdman, D.S. (1968). Recent fish records from Puerto Rico. Bull. Mar. Sci. Gulf Caribb. 6(4):315-340.

Fagade, S.O. (1979). Observation of the biology of two species of Tilapia from the Lagos lagoon Nigeria. Bull. Inst. Fond Afr. Nore (Ser. A), 41: 627-658.

Franks, J. S.; Warren, J. R. and Buchanan, M. V. (1999). Age and Growth of cobia, Rachycentron canadum, from the Northeastern Gulf of Mexico. Fishery Bulletin, 97(3), 459-471.

Froese, R. (2006). Cube law, condition factor and weight length relationships: history, meta-analysis and recommendations. J. Appl. Ichthyol. 22(4): 241-253

Froese, R.; Tsikliars, A.C. and Stergiou, K. I. (2011). Editorial note on weight-length relations of fishes. Acta Ichthyol. Piscat. 41, 261-263.

Fulton, T.W. (1904). The rate of growth of fishes. In: $22^{\text {nd }}$ Annual Report Fishery Board for Scotland, Fishery Board for Scotland, Scotland, UK, pp: 141-241.

Ganga, U., N. Pillai, G. K.; Akhilesh, K. V.; Rajoolshanis, C. P.; Beni, N.; Hashim, M.; and Prakashan, D. (2012). Population dynamics of cobia, Rachycentron canadum (Linnaeus, 1766) off Cochin coast, south-eastern Arabian Sea. Indian J. Fish., 59 (3): 15-20.

Herre, A.W. (1953). Check-List of Philippine Fishes. Research Report. US Department of Interior, Fish and Wildlife Service, Washington, DC. 977 pp. 
Joseph, E.B.; Norcross, J.J. and Massmann, W.H. (1964). Spawning of the cobia, Rachycentron canadum, in the Chesapeake Bay area, with observations of juvenile specimens. Chesapeake Sci. 5(1-2):67-71.

Kaiser, J. B. and G. J. Holt, (2005). Species profile of cobia. SRAC Pub., 7202: 1-6.

Kalinowsky, C. A.; Curran, M. C. and Smith, J. W. (2016). Age and growth of Rachycentron canadum (L.) (Cobia) from the Nearshore waters of South Carolina," Southeastern Naturalist 15(4): 714-728.

Kara, A., and Bayan, B. (2008). Length-weight and length-length relationships of the bogue, Boops boops (Linneaus, 1758) in Izmir Bay (Aegean Sea of Turkey). Belg. J. Zool., 138 (2): 154-157.

King, M. (2005). Fisheries Biology, Assessment and Management” Oxford, UK, Fishing News Books. Blackwell Science Ltd. 342 pp.

Le-Cren, E.D. (1951). The Length-weight relationship and seasonal cycle in gonadal weight and condition of perch (Perca fluviatilis). Journal of Animal Ecology, 20: 201-219.

Lotz, J. M.; Overstreet, R. M. and Franks, J. S. (1996). Gonadal maturation in the cobia, Rachycentron canadum, from the north central Gulf of Mexico. Gulf Res. Rep., 9: 147-159.

Maharshi, V.A. ; Murugan, A.; Srinivasa, Rao K.; Imelda, J.; Vijayanand, P.; Anbarasu, M.; Hanumanta Rao, G.; Abdul Nazar, A.K. and Gopakumar, G. (2017). Length weight relationship of cobia, Rachycentron canadum from hook and line fishery at Gulf of Mannar region, South East Coast of India. Indian Journal of Geo Marine Sciences. 46 (1): 107-110

Nikolsky, G.V. (1963). The ecology of fishes. Academy Press, London and New York" Xv $352 \mathrm{pp}$.

Pauly, D. (1983). Some simple methods for the assessment of tropical fish stocks. FAO Fishery Technical Paper. 234. 52 p. Food and Agriculture Organization of the United Nations, Rome.

Pillai, N. G. K.; Ganga, U. and Akhilesh, K. V. (2009). Some aspects of fishery and biology of cobia, Rachycentron canadum (Linnaeus, 1766) in the Indian Waters.

Rajan, S.; Patnaink, S.and Basu, N. C. (1968). New records of fishes from the Chilka Lake. J. Zool. Soc. India, 20(1/2): 80-93.

Richards, C.E. (1967). Age, growth and fecundity of the cobia, Rachycentron canadum, from Chesapeake Bay and adjacent mid-Atlantic waters. Trans. Am. Fish. Soc. 96(3):343-350.

Robins, C.R. and Ray, G.C. (1986). A Field Guide to Atlantic Coast Fishes of North America. Houghton Mifflin Company, Boston, MA. 354 pp.

Sajeevan, M. K. and Kurup, B. M. (2013). Evaluation of feeding indices of cobia, Rachycentron canadum (L. 1766) from north-west coast of India. J. Mar. Biol. Ass. India, 55(2): 16-21.

Sajeevan, M. K. and Kurup, B. M. (2014a). Osteological features of cobia, Rachycentron canadum (Linnaeus, 1766). J. Ocean Sci. Found., 11: 40-49.

Sajeevan, M. K. and Kurup, B. M. (2014b). Distribution and abundance of cobia, Rachycentron canadum (Linnaeus, 1766) occurring in Indian waters. Asian Fish. Sci., 27: 274-285. 
Sajeevan, M. K. and Madhusoodana, B. (2015). Length-weight relationship and condition factor of Cobia, rachycentron canadum (Linnaeus, 1766) along Northwest Coast of India. Fishery Technology 52:184-186.

Sajeevan, M. K. and Kurup, B. M. (2017). Length at first maturity of cobia, Rachycentron canadum (Linnaeus, 1766) from north-west coast of India. Indian J. Fish., 64(1): 72-74.

Shaffer, R.V. and Nakamura, E.L. (1989). Synopsis of biological data on the cobia, Rachycentron canadum (Pisces: Rachycentridae). NOAA Tech. Rep. NMFS 82, FAO Fisheries Synopsis 153pp.

Smith, J. W. (1995). Life history of cobia, Rachycentron canadum (Osteichthyes: Rachycentridae), in North Carolina waters. Brimleyana, 23: 1-23.

Snedecor, G.W. and Cochran, W.G. (1967). Statistical Methods, 593pp., Oxford and IBH Publishing Company, New Delhi India.

Sokal, R.R. and Rohlf, F.J. (1981). Biometry. W. H. Freeman and Company, San Francisco, California.

Somvanshi, V. S., Vargese, S.; Gulati, D. K.; and Bhargava, A. K. (2000). Some biological aspects of kingfish, Rachycentron canadum (Linnaeus, 1766) from the north-west Indian EEZ. Occational Paper, Fishery Survey of India, FSI, Mumbai, $36 \mathrm{pp}$.

Thompson, B. A.; Wilson, C. A.; Render, J. H.; and Beasley, M. (1991). Age, growth and reproductive biology of greater amberjack and cobia from Louisiana waters. Year 1. Rep. to U. S. Dep. Commer., NOAA, NMFS, Coop. Agreement NA90AA-H-MF089, Marine Fisheries Initiative (MARFIN) Prog., Coastal Fish. Inst., Louisiana St. Univ., Baton Rouge, 55pp.

Tonya, V. D.; Griffiths, S. P.; and. Fry, G. C (2010). Reproductive biology of the commercially and recreationally important cobia, Rachycentron canadum in north-eastern Australia. Fish. Sci., 76(1): 33-43.

Welcome, R.L. (1979). Fisheries Ecology of Flood Plain Rivers. Longman Press, London, pp: 317.

Williams, E. H. (2001). Assessment of cobia, Rachycentron canadum, in the waters of the U.S. Gulf of Mexico. NOAA Technical Memorandum NMFS-SEFSC-469, $54 \mathrm{pp}$. 